\title{
Profil Kasus Tetanus Anak Dí RS Prof. Dr. R.D. Kandou Manado
}

\author{
Novie H. Rampengan, Yose Pangestu, S.N.N Tatura, T.H Rampengan \\ Bagian Ilmu Kesehatan Anak Fakultas Kedokteran Universitas Sam Ratulangi/RSU Prof. Dr. R. D. \\ Kandou, Manado
}

\begin{abstract}
Latar belakang. Insiden dan angka kematian tetanus anak masih cukup tinggi di Indonesia. Di Bagian Ilmu Kesehatan Anak RSCM Jakarta, dari tahun 1990 sampai 1993 dirawat rata-rata 20,3 kasus tetanus anak per tahun dengan case fatality rate (CFR) berkisar antara 12,9 sampai 27,4\%. Laporan penelitian di Manado belum ada, maka diperlukan mengetahui profil penyakit tetanus anak yang dirawat di RS Prof. Dr. R.D. Kandou, Manado.

Tujuan. Mengetahui profil tetanus pada anak yang dirawat di RSUP Prof. Dr. R.D. Kandou Manado Metode. Review retrospektif anak yang didiagnosis tetanus di RS Prof. Dr. R.D. Kandou Manado dari Januari 2002-Januari 2012. Data dianalisis secara deskriptif.

Hasil. Empat puluh anak tetanus berusia 1-11 tahun, 65\% kasus laki-laki, dengan fokus infeksi terbanyak otitis media 21 (52,5\%). Sebagian besar (45\%) belum pernah mendapat imunisasi dasar terhadap tetanus. Masa inkubasi berkisar dari 5 hari sampai 1 bulan, dengan period of onset terpendek 10 jam. Komplikasi terbanyak bronkopneumonia (19 pasien) dan 6 pasien meninggal. Period of onset tetanus anak yang meninggal lebih singkat secara bermakna dibandingkan yang hidup $(1,12$ vs 3,32 hari $(\mathrm{p}=0,004))$, demikian pula antara tetanus berat dan ringan sedang $(1,85$ vs $3,85(\mathrm{p}=0,02))$. Lama perawatan rata-rata yang diberi antitoksin tetagam (buman antitetanus serum) tidak berbeda bermakna dibandingkan yang diberi ATS yaitu 11,5 vs 14,3 hari $(\mathrm{p}=0,440)$.

Kesimpulan. Pasien tetanus yang dirawat inap di RS Prof. Dr. R.D Kandou sejak 2002-2012 terbanyak adalah tetanus sedang. Sebagian besar pasien belum pernah diimunisasi terhadap tetanus. Period of onset pasien tetanus yang meninggal ataupun tetanus berat lebih singkat dibandingkan yang hidup ataupun tetanus ringan sedang. Lama rawat pasien yang diberi antitoksin tetagam dan ATS tidak berbeda. Sari Pediatri 2012;14(3):173-8.
\end{abstract}

Kata kunci: tetanus, masa inkubasi, Period of onset, tetagam

\footnotetext{
Alamat korespondensi:

Dr. Novie Homenta Rampengan, Sp.A, MCTM (TP). Bagian Ilmu Kesehatan Anak FK UNSRAT/RSUP Prof. R.D. Kandou Manado. Jl. Raya Tanawangko, Manado 95263, Indonesia. Telp. (0431) 821652; Fax. (0431) 859091. E-mail : novierampengan@yahoo.com
}

$\longrightarrow$ etanus atau lockjaw adalah penyakit akut yang menyerang sistem saraf pusat yang ditandai dengan kontraksi otot berkepanjangan. ${ }^{1}$ Gejala klinis utama yang diproduksi oleh spore-forming bakteri gram positif obligat anaerob Clostridium tetani. ${ }^{2,3}$ Infeksi 
seringkali timbul melalui luka yang terkontaminasi bakteri dan infeksi lain seperti otitis media. Apabila penyakit berlanjut maka akan terjadi pula spasme otot pada daerah mulut (trismus atau lockjaw), yang akan diikuti dengan kekakuan dan spasme pada seluruh otot di bagian tubuh yang lain.-8 Pasien dalam keadaan sadar penuh dan menampakkan ekspresi wajah kaku dan ketakutan akan timbul kembali spasme berulang. Masa inkubasi tetanus 3-21 hari. ${ }^{1,9,10}$ Tetanus masih menjadi masalah kesehatan masyarakat di Indonesia meskipun telah terjadi penurunan insidens sejalan dengan pelaksanaan program imunisasi terhadap tetanus. ${ }^{10-13}$ Di Indonesia, antara tahun 1990 sampai 1993 telah dirawat rata-rata 3363 kasus tetanus per tahun dengan case fatalitiy rate (CFR) berkisar antara 9,9 sampai 15,3\% (Dir Jen P2M-PLP Depkes RI). Di Departemen Ilmu Kesehatan Anak RSCM Jakarta, dari tahun 1990 sampai 1993 telah dirawat rata-rata 20,3 kasus tetanus anak per tahun dengan CFR berkisar antara 12,9 sampai $27,4 \% .{ }^{14}$ Untuk mengetahui profil penyakit tetanus pada anak yang dirawat di RS. Prof. Dr. R.D Kandou Manado, maka dilakukan penelitian.

\section{Metode}

Evaluasi dilakukan pada semua kasus tetanus pada anak yang dirawat pada tahun 2002-2012 di RS Prof. R.D. Kandou Manado yang merupakan
RS pendidikan Fakultas Kedokteran Universitas Sam Ratulangi (FK UNSRAT) Manado. Data medik secara retrospektif dikumpulkan dari rekam medik termasuk derajat tetanus, usia, gejala, fokus infeksi, lama perawatan, masa inkubasi, period of onset, komplikasi, riwayat imunisasi tetanus dan pemberian antitetanus. Masa inkubasi adalah interval antara waktu terjadi luka dan gejala awal tetanus. Period of onset adalah interval antara gejala awal dengan kejang pertama, sedangkan periode gejala klinis adalah waktu dari gejala awal sampai gejala kejang/kekakuan terakhir meliputi period of onset, progresifitas penyakit dan kesembuhan sampai remisi kejang. Sembuh dikatakan apabila tidak adanya kekambuhan kejang setelah penurunan dosis benzodiazepin. Data dianalisis secara deskriptif.

\section{Hasil}

Karakteristik 40 orang anak dengan diagnosis tetanus tertera pada Tabel 1 . Usia paling muda satu tahun dan tertua 11 tahun. Periode terkena luka atau otitis sampai muncul gejala atau yang disebut masa inkubasi berkisar antara 5 hari sampai 1 bulan. Delapan anak (20\%) memiliki masa inkubasi kurang 7 hari, 31 anak $(77,5 \%)$ dengan masa inkubasi $\geq$ 7 hari dan sisanya 1 anak (2,5\%) tidak diketahui secara pasti. Distribusi kasus tetanus berdasarkan gejala awal yang dilaporkan pada semua pasien adalah

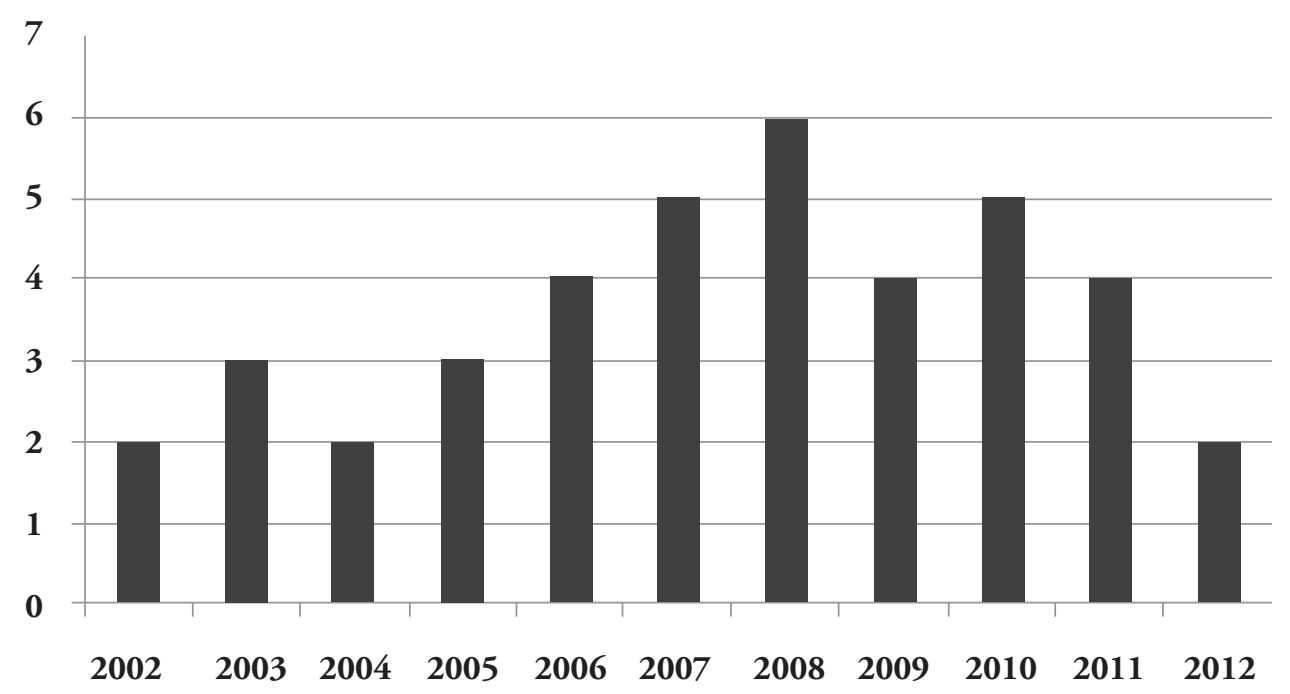

Gambar 1. Insidens tetanus anak, RSUP Prof. Dr. R D Kandou, 2002-2012 
Tabel 1. Karakteristik, klasifikasi, gejala klinis, pengobatan anti tetanus serum, dan komplikasi tetanus anak

\begin{tabular}{|c|c|c|}
\hline Parameter & $\mathrm{n}$ & Persentase \\
\hline \multicolumn{3}{|l|}{ Usia (tahun) } \\
\hline$<5$ & 20 & 50 \\
\hline $5-10$ & 18 & 45 \\
\hline$>10$ & 2 & 5 \\
\hline \multicolumn{3}{|l|}{ Jenis kelamin } \\
\hline Laki-laki & 26 & 65 \\
\hline Perempuan & 14 & 35 \\
\hline \multicolumn{3}{|l|}{ Klasifikasi } \\
\hline Ringan & 9 & 22,5 \\
\hline Sedang & 19 & 47,5 \\
\hline Berat & 12 & 30,0 \\
\hline \multicolumn{3}{|l|}{ Masa inkubasi (hari) } \\
\hline$<7$ & 8 & 20,0 \\
\hline$\geq 7$ & 31 & 77,5 \\
\hline Tidak diketahui & 1 & 2,5 \\
\hline \multicolumn{3}{|l|}{ Gejala spasme } \\
\hline trismus & 31 & 100,0 \\
\hline rhisus sardonicus & 7 & 22,6 \\
\hline kaku kuduk & 16 & 51,6 \\
\hline kejang & 15 & 48,4 \\
\hline opistotonus & 10 & 32,3 \\
\hline demam & 31 & 100,0 \\
\hline \multicolumn{3}{|l|}{ Lama rawat (hari) } \\
\hline$<7$ & 10 & 25,0 \\
\hline $7-14$ & 17 & 42,5 \\
\hline$>14$ & 13 & 32,5 \\
\hline \multicolumn{3}{|l|}{ Pemberian antitoksin } \\
\hline ATS & 30 & 75,0 \\
\hline Tetagam & 10 & 25,0 \\
\hline \multicolumn{3}{|l|}{ Komplikasi } \\
\hline \multicolumn{3}{|c|}{ Kardiovaskular (tetanus berat) } \\
\hline Takikardia & 7 & 17,5 \\
\hline Hipotensi & 1 & 2,5 \\
\hline Hiperpireksia & 7 & 17,5 \\
\hline Aritmia & 1 & 2,5 \\
\hline Hipokalemia & 1 & 2,5 \\
\hline Hiponatremia & 1 & 2,5 \\
\hline Bronkopneumonia & 19 & 47,5 \\
\hline Tidak ada komplikasi & 15 & 37,5 \\
\hline Meninggal & 6 & 15,0 \\
\hline
\end{tabular}

trismus, kejang, panas, opistotonus dan kekakuan pada leher. Kasus terbanyak $(47,5 \%)$ adalah tetanus sedang, diikuti tetanus berat sebanyak 12 anak (30\%) sedangkan tetanus ringan menduduki porsi terkecil $(22,5 \%)$. Pemberian antiserum tetanus sebanyak 75\% mendapat ATS dan sisanya mendapatkan human antitetanus serum (Tetagam). Komplikasi terjadi pada 19 anak. Komplikasi yang banyak terjadi adalah bronkopneumonia pada 19 anak, kematian karena gagal napas pada 6 anak dan sisanya 15 anak tidak mengalami komplikasi.

Gambaran fokus infeksi tertera pada Tabel 2. Sebagai fokus infeksi pada anak dengan tetanus yang diteliti adalah otitis media pada 21 anak (52,5\%) diikuti $32,5 \%$ berupa luka tusuk. Berdasar lokasi luka, setelah infeksi di telinga, 9 (22,5\%) anak dengan luka di lutut ke bawah, sisanya luka pada kepala, luka pada tangan, dan luka pada lutut ke atas masing-masing sebesar 7,5\%. Status imunisasi subjek, sebagian besar kasus (45\%) belum mendapatkan imunisasi dasar tetanus sedangkan $30 \%$ kasus sudah diberikan imunisasi tetanus dasar yang lengkap, namun tanpa booster.

Pasien tetanus yang dirawat memiliki riwayat masa inkubasi berkisar 5 hari sampai 1 bulan, dengan period of onset terpendek 10 jam. Empat dari 6 anak yang meninggal memiliki masa inkubasi $\leq 7$ hari. Lima dari 6 anak yang meninggal dengan lama perawatan $<2$ hari dan 1 anak dengan lama perawatan 15 hari di rumah sakit. Pada tetanus berat memiliki masa inkubasi, period of onset, periode gejala klinis, dan lama perawatan lebih singkat dibandingkan tetanus ringan sedang. Tetapi hanya variabel period of onset pada tetanus berat yang lebih singkat bermakna secara statistik dibandingkan dengan tetanus ringan sedang $(1,85$ vs 3,45 hari, $\mathrm{p}=0,02)$. Riwayat imunisasi

Tabel 2. Lokasi luka sebagai port'd entrée dan tipe luka

\begin{tabular}{lcccc}
\hline \multirow{2}{*}{ Lokasi dan tipe luka } & \multicolumn{3}{c}{ Klasifikasi, n $(\%)$} \\
\cline { 2 - 3 } & Ringan & Sedang & Berat & Jumlah \\
\hline Lokasi & $1(2,5)$ & $6(15)$ & $2(5)$ & $9(22,5)$ \\
Lutut ke bawah & $1(2,5)$ & $1(2,5)$ & $1(2,5)$ & $3(7,5)$ \\
Lutut ke atas & $1(2,5)$ & $1(2,5)$ & $1(2,5)$ & $3(7,5)$ \\
Tangan & - & $2(5)$ & $1(2,5)$ & $3(7,5)$ \\
Kepala & $5(12,5)$ & $9(22,5)$ & $7(17,5)$ & $21(52,5)$ \\
Telinga & $1(2,5)$ & - & - & $1(2,5)$ \\
Tidak teridentifikasi & $1(2,5)$ & $3(7,5)$ & $2(5)$ & $6(15)$ \\
Tipe & $5(12,5)$ & $5(12,5)$ & $3(7,5)$ & $13(32,5)$ \\
$\quad$ Luka laserasi & $6(15)$ & $8(20)$ & $7(17,5)$ & $21(52,5)$ \\
$\quad$ Luka tusuk & & & & \\
$\quad$ Infeksi & &
\end{tabular}


Tabel. 3. Perbedaan Karakteristik klinis dan riwayat imunisasi antara tetanus ringan sedang dan berat

\begin{tabular}{lccc}
\hline Variabel & $\begin{array}{c}\text { Tetanus ringan-sedang } \\
\text { (hari) }\end{array}$ & $\begin{array}{c}\text { Tetanus berat } \\
\text { (hari) }\end{array}$ & $\mathrm{p}$ \\
\hline Periode inkubasi & 13,97 & 11,62 & 0,54 \\
Period of onset & 3,45 & 1,85 & 0,02 \\
Periode gejala klinis & 18,93 & 13,78 & 0,017 \\
Lama rawat & 13,79 & 11,24 & 0,23 \\
Imunisasi, n (\%) & & & \\
$\quad$ Lengkap & $9(22,5)$ & $3(7,5)$ & 0,355 \\
$\quad$ Tidak lengkap & $7(17,5)$ & $2(5,0)$ & \\
\multicolumn{1}{l}{ Tidak pernah } & $12(30,0)$ & $7(17,5)$ & \\
\hline
\end{tabular}

Tabel 4. Perbedaan masa inkubasi dan period of onset menurut prognosis

\begin{tabular}{lccc}
\hline Rerata & $\begin{array}{c}\text { Sembuh } \\
(\mathrm{n}=34)\end{array}$ & $\begin{array}{c}\text { Meninggal } \\
(\mathrm{n}=6)\end{array}$ & $\mathrm{p}$ \\
\hline Masa inkubasi & 14,03 & 10 & 0,309 \\
Period of onset & 3,32 & 1,12 & 0,004 \\
\hline
\end{tabular}

Tabel 5. Perbedaan lama rawat tetanus anak yang diberi ATS dan Tetagam

\begin{tabular}{lccc}
\hline Jenis antitetanus & Jumlah & $\begin{array}{c}\text { Lama rawat } \\
\text { (hari) }\end{array}$ & $\mathrm{p}$ \\
\hline Tetagam & 10 & 10 & \\
ATS & 30 & 14,24 & 0,440 \\
\hline
\end{tabular}

pada kelompok tetanus berat 7 dari 12 pasien belum pernah mendapat imunisasi sama sekali sedangkan pada kelompok dengan tetanus ringan-sedang hanya didapat 12 dari 28 pasien, namun perbedaan tersebut tidak bermakna (Tabel 3).

Period of onset pasien tetanus yang meninggal lebih singkat dibandingkan yang hidup 1,12 vs 3,32 hari $(\mathrm{p}=0,004)$, begitu juga antara tetanus berat dan ringan sedang 1,85 vs 3,85 hari $(\mathrm{p}=0,02)$ (Tabel 4). Perawatan rata-rata pasien yang diberi antitoksin tetagam tidak berbeda bermakna dibandingkan yang diberi ATS 11,5 vs 14,3 hari $(\mathrm{p}=0,440)($ Tabel 5$)$.

\section{Pembahasan}

Studi berikut mencatat dan menganalisis secara deskriptif anak dengan diagnosis tetanus yang dirawat di RS Prof. Dr. R.D. Kandou Manado Januari 2002 Januari 2012. Distribusi usia kasus tetanus bervariasi. Di negara berkembang, tetanus seringkali terjadi pada kelompok usia lebih muda karena berkaitan dengan higiene dan sanitasi yang kurang baik sehingga memudahkan mereka terkontaminasi dan terinfeksi. Perawatan luka yang kurang mendapat perhatian dan kesadaran masyarakat yang kurang akan imunisasi juga merupakan suatu penyebab insidens tetanus pada anak masih tinggi. ${ }^{15-17}$ Di Amerika (1915) dilaporkan tetanus dominan pada usia 1-5 tahun, ${ }^{1,18}$ sedangkan di Surabaya $(1987)^{4}$ dominan pada usia di atas 5 tahun. Pada studi kami terdapat 40 anak yang terdiagnosis tetanus dengan usia antara 1-11 tahun dengan usia terbanyak kurang dari 5 tahun. Hal tersebut serupa dengan hasil temuan Geeta $\mathrm{dkk}^{19}$ yang mendapatkan $53 \%$ kasus tetanus berumur $<5$ tahun.

Kami mendapatkan tetanus anak lebih banyak terjadi pada anak laki-laki (65\%), sesuai dengan laporan Muller $\mathrm{dkk}^{20}$ yang mendapatkan pasien lakilaki 70\%, kemungkinan berkaitan dengan aktivitas di luar rumah dan beberapa penulis menyebutkan kemungkinan terdapat faktor biologi pada lakilaki lebih sensitif terhadap toksin tetanus daripada perempuan. ${ }^{21-23}$

Fokus infeksi tetanus pada studi kami terbanyak adalah otitis media $(52,5 \%)$ dan sisanya $(47,5 \%)$ infeksi luka tusuk dan laserasi pada ekstremitas dan kepala. Berbeda dengan hasil temuan Poudel $\mathrm{dkk}^{24}$ yang menyebutkan bahwa mayoritas (32\%) kasus tetanus diakibatkan dari luka laserasi, dan 16\% akibat dari otitis media. Temuan lain oleh Geeta $\mathrm{dkk}^{19}$ senada dengan hasil studi kami, yang mengatakan bahwa $58 \%$ kasus fokus infeksi berasal dari otitis media dan $30 \%$ akibat luka. Temuan tersebut menekankan akan pentingnya pengobatan awal dan optimal terhadap infeksi telinga tengah pada anak. Kenyataannya bahwa tetanus seharusnya dapat dicegah dengan kesadaran masyarakat terhadap masalah higiene, sanitasi, serta perawatan luka yang baik dan segera, serta kesadaran akan pentingnya imunisasi. ${ }^{16,25,26}$ 
Masa inkubasi kasus tetanus berat cenderung lebih pendek, namun masa inkubasi panjang tidak selalu menjamin terjadi serangan lebih ringan. Periode onset adalah interval antara gejala pertama dan kejang pertama, dan ini juga berkorelasi dengan keparahan serangan. Masa inkubasi pada penelitian kami berkisar antara 5 hari sampai 1 bulan dengan rerata 13,4 hari. Semakin jauh lokasi luka dari sistem saraf pusat (SSP), makin lama masa inkubasi. ${ }^{27,28}$ Apabila dibandingkan antara tetanus ringan sedang dan berat, terdapat perbedaan pada period of onset dan periode gejala klinis. Semakin singkat period of onset semakin berat gejala klinis tetanus. Masa inkubasi tetanus berat lebih singkat dibanding tetanus ringan sedang (13,97 vs 11,62 hari) namun tidak dijumpai perbedaan bermakna.

Case fatality rate bervariasi dan bergantung pada panjang masa atau periode inkubasi dan juga bergantung pada kualitas perawatan medis. ${ }^{29}$ Masa inkubasi dan period of onset yang lama berkaitan dengan semakin lama pasien bertahan hidup, jadi masa inkubasi menunjukkan hubungan terbalik dengan mortalitas. ${ }^{16,30}$ Disparitas waktu saat mulai timbul gejala awal dan onset konvulsi sangat signifikan. Hal tersebut merupakan petunjuk prognostik yang penting, semakin singkat period of onset, semakin buruk prognosis. ${ }^{30}$ Pada studi kami, masa inkubasi dan period of onset pada pasien yang meninggal lebih singkat dibanding yang sembuh, tetapi hanya variabel period of onset yang memiliki perbedaan. Tiga dari 6 orang anak yang meninggal memiliki masa inkubasi 7 hari, satu orang anak dengan masa inkubasi 5 hari dan sisanya lebih dari 14 hari. Lima dari 6 anak yang meninggal memiliki lama perawatan kurang dari 2 hari, dengan lama rawat tersingkat adalah 10 jam dan satu anak dengan lama rawat 15 hari. Period of onset pada pasien tetanus yang meninggal lebih singkat bermakna dibandingkan pasien yang sembuh $(1,12$ vs 3,32 hari, $\mathrm{p}=0,004)$. Masa inkubasi, secara statistik tidak memiliki perbedaan. Hasil temuan tersebut senada dengan hasil temuan Poudel $\mathrm{dkk}^{24}$ bahwa masa inkubasi tidak berbeda bermakna ( 8,8 hari vs 7,31 hari, $\mathrm{p}=0,735)$ tapi period of onset berbeda antara pasien yang sembuh dan yang meninggal (27,8 jam vs 12,76 jam, $\mathrm{p}=0,005)$. Komplikasi terjadi pada $47,5 \%$ kasus berupa bronkopneumonia dengan kematian karena gagal napas pada 6 anak, sedangkan sisanya tanpa komplikasi. Enam diantara 12 orang anak dengan tetanus berat meninggal dunia.
Distribusi berdasarkan gejala awal tetanus yang terjadi adalah trismus, rhisus sardonicus, kejang, panas, opistotonus, dan kekakuan pada leher dijumpai pada semua pasien. Pasien mendapatkan pengobatan sesuai protokol pengobatan tetanus yang meliputi eliminasi bakteria dengan antibiotik, netralisasi toksin dengan ATS atau tetagam, cairan dan nutrisi, pembebasan jalan napas dan oksigenasi, menghilangkan kejang dengan diazepam $0,1-0,3 \mathrm{mg} / \mathrm{kgBB} / \mathrm{kali}$ dan luminal $15 \mathrm{mg} /$ $\mathrm{kgBB} / \mathrm{kali} .4,5$

Delapan belas dari anak tetanus pada studi kami belum pernah mendapat imunisasi dasar tetanus, sisanya pernah imunisasi dasar tetanus namun tidak lengkap dan belum pernah imunisasi ulangan. Diantara 6 kasus yang meninggal dunia, empat orang belum diimunisasi. Temuan ini mengingatkan pentingnya imunisasi aktif terhadap tetanus pada anak. Kesadaran masyarakat dan pelayanan kesehatan harus ditingkatkan dalam menurunkan angka mortalitas dan morbiditas tetanus pada anak.

\section{Daftar pustaka}

1. Rampengan TH. Penyakit infeksi tropik pada anak. Edisi ke-2. Jakarta:Penerbit Buku Kedokteran EGC, 2008.h. 32-45.

2. Phillips DL. Do DTP and tetanus vaccinations cause asthma? Diakses dari http://www//suite101.com.

3. Centres for Disease Control . Tetanus United States 1982-1984. JAMA 1985; 254: 2873-8.

4. Ismoedijanto, Parwati SB. Tetanus. Dalam: Soegijanto $S$, penyunting. Penyakit Tropis dan Infeksi di Indonesia. Surabaya:Airlangga University Press, 2004. h. 111-9.

5. Ikatan Dokter Anak Indonesia. Tetanus. Dalam: Soedarmo SSP, Garna H, Hadinegoro SRS, Satari SI, penyunting. Buku Ajar Infeksi dan Penyakit Tropis. edisi ke-2. Jakarta:Badan Penerbit IDAI, 2008. h. 322-30.

6. Arnon S.S. Tetanus. Dalam: Behrman RE, Kliegman R, Arvin AM. penyunting. Nelson Ilmu Kesehatan Anak. edisi ke-15. Jakarta:Balai Penerbit EGC, 2002. h. 1004-7.

7. Freeman J. Tetani. Dalam: Burrows, penyunting. Textbook of Microbiology. Edisi ke-22. Philadelphia:W.B.Saunders, 1985. h.576-80.

8. Padmakumar B, Date AR. Tetanus in an unvaccinated child in the United Kingdom case report. J Public Health 2004; 10:1-2.

9. Mehta P. Tetanus in children. Mehta Child 2007; 45:1-3. 
10. Lestar W, Widyaningrum D, Sumarno, Siburian F. Immunnity to diptheriae and tetanus of primary school drop out children in North Jakarta Municipality. Buletin Penelitian Kesehatan 2002; 202:152-6.

11. Davila CAM, Donis JH, Gonzalo X. Autonomic nervous system dysfunction in children with severe tetanus: dissociation of cardiac and vascular sympathetic control. Braz J Med Res 2003; 36:815-9.

12. Goldwater PN, Mayer AJB, Power RG, Henning PH, Gold MS, Donald TG, dkk. Childhood tetanus in Australia: ethical issues for a should be forgotten preventable disease. MJA 2003; 178:175-7.

13. Departemen Kesehatan RI. Ditjen PPM \& PLP. Pedoman Pelaksanaan Program Imunisasi di Indonesia, 2000.

14. Kumar R, Taneja DK, Dabas P, Ingle GK, Saha R. Knowledge about tetanus immunization among doctors in Delhi. Indian J Med Sci 2005; 59:3-8.

15. Akbar P. Neonatal tetanus. Pak J Paed 1981; 5:57-64.

16. Pawar AB, Kumavat AP, Bansal RK. Epidemiological study of tetanus cases admitted to a referral hospital in Solapur. Indian J Ped 2004; 29:1-3.

17. Galazka A, Birmingham M, Kurian M, FL Gasse. Tetanus in global epidemiology of infectious disease. Pediatr Infect Dis J 1995; 6:151-88.

18. Blake PA, Feldman RA, Buchanan TM, Brooks GF, Bennett JV. Serologic therapy of tetanus in the United States. JAMA 1976; 235:42-4.

19. Geeta MG, Khrisnakumar P, Mathews L. Intrathecal tetanus immunoglobulins in the management of tetanus. Indian J Ped 2007; 74:43-5.
20. Garnier MJ, Deschapelles. Tetanus in patients three years of age and up. Am J Surg 1975; 129:429-53.

21. Bytchenko B. Geographical distribution of tetanus in the world a review of the problem. Bull WHO 1966; 34:71-104.

22. Ebisawa I. Mortality and sex difference of tetanus in Japan. Jap J Exp Med 1971; 41:21-9

23. Ebisawa I, Homma R. Tetanus in Japan : trends of mortality, case fatality and causes of death. Jap J Exp Med 1986; 56:155-61.

24. Poudel P, Singh R, Raja S, Budhathoki S. Pediatric and neonatal tetanus: a hospital based study at eastern Nepal. Nepal Med Coll J 2008; 10:170-5.

25. Patodi RK. A study of tetanus patients admitted at MT and MY Hospital Indore. Indian J Prev Med 1974; 5:55-8.

26. Afonja AO. Tetanus in Lagos a review of 228 adult Nigerian patients. J Trop Med 1973; 76:171-4.

27. Abuwa PNC. Epidemiology of neonatal tetanus in Rivers State of Nigeria. J of Epidemiol and Comm Health 1996; 51:336-9.

28. Centre for Disease Control. Diphteria, tetanus and pertusis guidelines for vaccine prophylaxis and other preventive measure. JAMA 1985; 254:895-900.

29. Einterz EM, Bates ME. Caring for neonatal tetanus patients in a rural primary health setting in Nigeria: A review of 237 cases. J Trop Ped 1991; 37:179-81.

30. Cole L. The treatment of tetanus with observations on the rate of injected antitoxin. Quarterly. J Med 1935; 4:295-7. 